\title{
Evidence for a role for a uterine renin-angiotensin system in decidualization in rats
}

\author{
P. M. Squires ${ }^{1}$ and T. G. Kennedy ${ }^{1,2}$ \\ Departments of ${ }^{1}$ Physiology and ${ }^{2}$ Obstetrics and Gynaecology, The University of Western Ontario, \\ London, Ontario, Canada N6 A CI
}

\begin{abstract}
Summary. Experiments were performed in vivo and in vitro to determine the effects of enalaprilat, a specific inhibitor of angiotensin-converting enzyme, on various aspects of the decidual cell reaction in rats. Ovariectomized, adult female rats were sensitized for the decidual cell reaction with steroid treatments. For in vivo experiments, intrauterine infusions of enalaprilat alone, and in combination with angiotensin II and prostaglandin $\mathrm{E}_{2}\left(\mathrm{PGE}_{2}\right)$, were initiated on the day of uterine sensitivity. Enalaprilat inhibited the increases in uterine PG concentrations, endometrial vascular permeability, alkaline phosphatase activity and uterine weight that occurred sequentially following infusion of vehicle. Concurrent infusion of angiotensin II did not reverse any of these inhibitory effects; $\mathrm{PGE}_{2}$ infusion partially, but not completely, reversed the inhibition of increase in uterine weight, although it did not alter the inhibition of endometrial vascular permeability. For in vitro experiments, endometrial stromal cells were obtained from uteri on the day of sensitivity and cultured for up to 3 days in the presence of enalaprilat and angiotensin II. Enalaprilat inhibited in a dose-dependent manner the increases in stromal cell alkaline phosphatase activity and media PGE concentration that occurred in the control cultures; these effects were fully reversed by concurrent treatment with angiotensin II. The inhibition of stromal alkaline phosphatase activity was also reversed by $\mathrm{PGE}_{2}$; conversely, the ability of angiotensin II to reverse the effect of enalaprilat was lost in the presence of indomethacin. These studies provide evidence of a requirement for angiotensin II during the decidual cell reaction in rats and suggest that it acts, at least in part, through a PG-dependent mechanism.
\end{abstract}

Keywords: angiotensin; decidualization; prostaglandins; uterus; rat

\section{Introduction}

In species in which implantation of the blastocyst is invasive, the endometrium undergoes a response termed the decidual cell reaction, a response that can also be artificially induced by the application of various stimuli to the sensitized uterus (Psychoyos, 1973). The processes accompanying decidualization (the differentiation of endometrial stromal cells into decidual cells) include a number of changes in the uterine vasculature. It is well established that an increase in endometrial vascular permeability precedes implantation and decidualization, and appears to be a prerequisite for these events (Psychoyos, 1973; Kennedy, 1986). In addition, enlargement of uterine blood vessels and extensive neovascularization of the uterus occur after application of stimuli that induce decidualization (Lobel et al., 1965), as does a rapid increase in uterine blood flow (Edwards \& Milligan, 1987). Prostaglandins (PGs), particularly those of the E series, have been implicated as key mediators of the increased endometrial vascular permeability and subsequent decidualization; it has also been suggested that the production of other vasoactive mediators, in addition to PGs, by the endometrium may be essential for some of these reactions to occur (Kennedy, 1980a). 
The octapeptide angiotensin II increases vascular permeability (Robertson \& Khairallah, 1972) and is angiogenic (Fernandez et al., 1982; Fernandez et al., 1985). There is substantial evidence for the local production of this peptide and for the presence of the enzymes for its synthesis, renin and angiotensin-converting enzyme, in the uteri of a number of species (Cushman \& Cheung, 1971; Deboben et al., 1983; Naruse et al., 1985), including rats. Specific and saturable angiotensin II binding has also been demonstrated in rat uterus (Lin \& Goodfriend, 1970).

Administered angiotensin II increases uterine blood flow in pregnant sheep (Bruce et al., 1981) and monkeys (Speroff et al., 1977); in the latter, this response is inhibited by indomethacin, a blocker of PG synthesis. Conversely, inhibition of angiotensin-converting enzyme reduces blood flow and PGE production in the uterus of pregnant rabbits (Ferris \& Weir, 1983). These results suggest indirectly that angiotensin II might also be involved in the increased uterine blood flow and PG concentration responses that occur during the decidual cell reaction.

The studies reported here investigated a role for angiotensin II in decidualization in rats by determining the effects of inhibition of endometrial angiotensin II synthesis on this reaction, on the assumption that if angiotensin 11 directly or indirectly mediates the endometrial vascular responses that occur during the decidual cell reaction, then inhibiting its synthesis would reduce the extent of decidualization. We studied the effects of intrauterine infusion of enalapril and enalaprilat, specific inhibitors of angiotensin-converting enzyme, on various aspects of the decidual cell reaction in ovariectomized, steroid-treated rats. Enalaprilat (MK 422: $N$-[(S)-1-(carboxy)-3-phenylpropyl]L-Ala-L-Pro) is the active diacid form of the prodrug enalapril (MK 42]: $N$-[S-1-ethoxycarbonyl-3phenylpropyl]-L-Ala-L-Pro), a noncompetitive, active-site-directed inhibitor of angiotensin-converting enzyme (Oparil, 1983). Enalapril, wheñ administered systemically, requires hepatic metabolism for biological activity; when administered intraluminally, an effect of enalaprilat but not of enalapril is expected.

An increase in alkaline phosphatase activity in the endometrial stroma is associated with decidualization (Lobel et al., 1965) and early pregnancy (Christie, 1966; Manning et al., 1969). This increase is maximal $24-72 \mathrm{~h}$ after the induction of decidualization and provides a good index of endometrial differentiation. Measurements of endometrial alkaline phosphatase activity, uterine weight, endometrial vascular permeability and uterine PG concentration were used to assess the effects of inhibition of angiotensin-converting enzyme on the decidual cell reaction.

\section{Materials and Methods}

\section{Animals}

Female Sprague-Dawley rats were obtained from Charles River Inc. (St Constant, PQ, Canada) and were housed under temperature- and light-controlled conditions (lights on from 05:00 to 19:00 h) with free access to food and water.

\section{Treatments}

Rats weighing 200-225 g were ovariectomized under ether anaesthesia and allowed at least 6 days to recover from surgery. To obtain rats sensitized for the decidual cell reaction, oestradiol and progesterone were given subcutaneously to the animals in the sequence described by Kennedy (1985). For animals used for in vitro experiments, the injection sequence was terminated on the equivalent of day 5 of pseudopregnancy.

\section{In vivo preparation: intrauterine infusions}

Alzet osmotic minipumps model 2001 (pumping rate $1 \mu \mathrm{h} \mathrm{h}^{-1}$; Alza Corp., Palo Alto, CA) were used for the unilateral intrauterine infusion of compounds into the uterine lumen. All compounds were delivered in a sodium phosphate buffer $\left(0.05 \mathrm{~mol}^{-1}, \mathrm{pH} 7.4\right)$ containing $20 \%$ dimethyl sulfoxide. The angiotensin-converting enzyme inhibitors enalapril and enalaprilat (both supplied by A. Prat, Merck Frosst Canada Inc., Dorval, PQ, Canada) were dissolved in the vehicle in concentrations up to $30 \mathrm{mg} \mathrm{ml}^{-1}$, whereas control animals received infusions containing mannitol in concentrations determined to give equivalent osmolarities with the enalaprilat solutions. Mannitol sugar 
that is not metabolized and is of low molecular mass $(0.182 \mathrm{kDa}$ versus $0.3483 \mathrm{kDa}$ for enalaprilat) was used as a control for the possible effects of a hyperosmotic infusate on decidualization. In some experiments, angiotensin II or angiotensin III (Sigma Chemical Co., St Louis, MO, USA), PGE $_{2}$ or PGF $_{2 a}$ tromethamine (Upjohn Diagnostics, Kalamazoo, MI, USA) were infused simultaneously with enalaprilat.

The empty pumps were incubated overnight at room temperature in $0.9 \% \mathrm{NaCl}$ and were filled with the freshly prepared solutions just before being implanted into the animals. The technique for inserting the minipumps has been described by Kennedy \& Lukash (1982). One uterine horn of each animal was infused from the uterotubal end toward the cervical end with the contralateral noninfused horn serving as a control.

\section{In vitro preparation: cell cultures}

Between 08:00 and 08:30 on day 5, all rats were killed by decapitation. Uteri were excised from above the cervices and trimmed of adherent tissues. The horns were separated, slit longitudinally and placed in Hank's balanced salt solution without calcium and magnesium (HBSS; GIBCO, Grand Island, NY). Endometrial stromal cells were isolated from the uteri by enzymatic digestion by a modification of the methods described by McCormack \& Glasser (1980) and Yee \& Kennedy (1991). Cells were plated at $5 \times 10^{5}$ cells per well (containing $1 \mathrm{ml}$ of medium) in Falcon multiwell tissue culture plates (Becton-Dickinson; Lincoln Park, NJ). The preparations were further purified by allowing an initial $2 \mathrm{~h}$ pre-attachment period during which the fibroblastic stromal cells adhered readily to the plates, while the residual epithelial cells and blood cells were removed during exchange of media. Stromal cells were cultured for up to 3 days with enalaprilat, $\mathrm{PGE}_{2}$ or indomethacin (Sigma) in ethanol, and with varying doses $\left(0-10 \mu \mathrm{g} \mathrm{ml}^{-1}\right)$ of angiotensin II dissolved in culture medium and sterilized by filtration. The concentration of ethanol in the medium did not exceed $1 \%$; cells not receiving enalaprilat, $\mathrm{PGE}_{2}$ or indomethacin were treated with an equivalent volume of ethanol. Similarly, cells not receiving angiotensin II received an equivalent concentration of bovine serum albumin. Medium containing the appropriate additions was replaced every $24 \mathrm{~h}$.

\section{Decidualization in vivo}

Rats were killed 5 days after the insertion of pumps and the uterine horns were excised, trimmed of adhering fat and blotted on filter paper. The extent of uterine decidualization was assessed by weighing the infused and non-infused horns separately (Finn \& Keen, 1963; Yochim \& DeFeo, 1963).

\section{Endometrial vascular permeability}

Changes in endometrial vascular permeability were measured $10 \mathrm{~h}$ after the initiation of the infusions, using ${ }^{125}$ I-labelled bovine serum albumin ( ${ }^{125}$ I-labelled BSA) as described by Kennedy (1979). Fifteen minutes before autopsy, the rats were given an i.v. injection of $8 \times 10^{6}$ c.p.m. per $250 \mathrm{~g}$ body weight of ${ }^{125} \mathrm{I}$-labelled BSA in saline. The animals were killed and concentrations of radioactivity in serum and in the infused and noninfused horns determined.

\section{Measurement of alkaline phosphatase activity}

For assessment in vivo, rats were killed 2 days after pump insertion; uterine horns were excised, washed in $0.9 \%$ $\mathrm{NaCl}$, and slit longitudinally. The endometria were scraped mechanically from the myometria, homogenized in glassteflon bomogenizers in $0.25 \%$ sucrose, and homogenates were frozen until assayed for alkaline phosphatase activity.

Alkaline phosphatase activity of cultured stromal cell was assessed by removing medium at the end of the culture period and washing cells with Dulbecco's phosphate-buffered saline (GIBCO). Some cells were lysed with $0 \cdot 25 \%$ sodium deoxycholate, $\mathrm{pH} 8$ (Sigma), and frozen at $-70^{\circ} \mathrm{C}$ until assayed for alkaline phosphatase activity. The remaining cultures were frozen at $-20^{\circ} \mathrm{C}$ until assayed for protein content. Alkaline phosphatase activity was measured spectrophotometrically as described by Lowry (1957), with activities expressed as nmol of the product ( $p$-nitrophenol; pNP) produced in $30 \mathrm{~min}$ per $\mu \mathrm{g}$ protein (as assessed by the methods of Lowry et al., 1951, using BSA as the standard). Enalaprilat, angiotensin II, $\mathrm{PGE}_{2}$ and indomethacin did not interfere with alkaline phosphatase determination when added directly to assay tubes.

\section{Measurement of PG concentrations}

The radioimmunoassays used to determine the concentrations of $P G s$ of the $E$ and $F$ series are described in Kennedy $(1979,1980 \mathrm{~b})$. For measurements of $\mathrm{PG}$ concentration in uterine homogenates, rats were decapitated $3 \mathrm{~h}$ after pump insertion, and the uteri were removed and placed in ice-cold $0.9 \%$ saline containing $20 \mu \mathrm{g}$ indomethacin $\mathrm{ml}^{-1}$ to block further PG synthesis. After at least $1 \mathrm{~min}$ in this solution, the uterine horns were cleaned, blotted and frozen on dry ice. The tissue was weighed, placed in ice-cold ethanol and stored at $-20^{\circ} \mathrm{C}$. Samples were later homogenized at $4^{\circ} \mathrm{C}$ in Ten Broeck homogenizers and centrifuged at $1000 \mathrm{~g}$ for $15 \mathrm{~min}$.

For measurement of PGE in cultures, medium was collected from cells at the time of freezing, centrifuged at $2000 \mathrm{~g}$ to remove cellular debris and stored at $-20^{\circ} \mathrm{C}$ until extracted. Extraction of PGs was performed by acidifying thawed 
medium with $1 \mathrm{~mol} \mathrm{HCl}^{-1}$ to $\mathrm{pH}$. The acidified medium was extracted with diethyl ether, frozen in a bath of methanol and dry ice, and supernatants were poured off and dried under $\mathrm{N}_{2}$; the extraction was repeated twice.

All supernatants were dried under $\mathrm{N}_{2}$, brought up in $1 \mathrm{ml}$ ethanol, and assayed in triplicate for prostaglandin $\mathrm{E}$, using $\mathrm{PGE}_{2}$ as a standard; homogenate extracts were also assayed for $\mathrm{PGF}_{2 \pi}$. The intraassay coefficients of variation of the PGE and PGF ${ }_{2 a}$ assays were $4 \%$ and $8 \%$, respectively. Recovery of tritiated $\mathrm{PGE}_{2}$ from fresh (not exposed to cells) culture medium was $86 \%$, whereas recovery of unlabelled $\mathrm{PGE}_{2}$ was $80 \cdot 5 \%$. Enalaprilat, angiotensin II and indomethacin did not interfere with assay results when added directly to homogenates or medium samples before extraction.

\section{Statistical analysis}

Data were expressed as means \pm SEM. For in vivo experiments logarithmic transformation of the data was performed to reduce heterogeneity of variance, as determined by Bartlett's test (Snedecor \& Cochrane, 1967). The significance of treatment effects was determined by mixed-model analysis of variance (Snedecor \& Cochrane, 1967), the variance being partitioned on a within-animal and between-animal basis. Duncan's new multiple range test (Steele \& Torrie, 1960) was used for between-animal comparisons when significant interactions were found. For in vitro experiments, the significance of treatment effects was assessed by analysis of variance and Duncan's new multiple test (Steele \& Torrie, 1960).

\section{Results}

\section{Dose-response relationship between rate of infusion of angiotensin-converting enzyme inhibitors and the decidual cell reaction}

There was no significant difference between groups treated with the angiotensin-converting enzyme inhibitor enalaprilat and control groups in the weights of noninfused uterine horns in this or any subsequent experiment (Fig. 1). Infusion of the vehicle containing mannitol $\left(25 \cdot 1 \mathrm{mg} \mathrm{ml}^{-1}\right)$ but no enalaprilat induced an 11 -fold increase in the weight of infused uterine horns compared with the noninfused uterine horns. Analysis of variance indicated a significant $(P<0.001)$ dosedependent inhibitory effect of enalaprilat on the weights of the infused uterine horns, interpreted as an inhibitory effect on the decidual cell reaction. Duncan's new multiple range test demonstrated that the weights of uterine horns infused with enalaprilat at 2.5 or $25 \mu \mathrm{g} \mathrm{h}^{-1}$ were significantly lower than the weights of vehicle plus mannitol-infused uterine horns $(P<0.05)$, whereas the lower rates of infusion had no significant effect. By contrast, infusion of enalapril did not inhibit decidualization $(P>0.05)$; infusion of enalapril at rates of $0,0.3,3$ and $30 \mu \mathrm{g} \mathrm{h}^{-1}$ resulted in uterine weights of $1238 \pm 149,1090 \pm 216,1043 \pm 141$ and $859 \pm 132 \mathrm{mg}$ (mean \pm SEM), respectively. Since $25 \mu \mathrm{g} \mathrm{h}^{-1}$ enalaprilat produced more inhibition $(P<0.01)$ than did the $2.5 \mu \mathrm{g} \mathrm{h}^{-1}(P<0.01)$, the former was used in subsequent experiments.

\section{Effects of concurrent infusion of angiotensin II or $\mathrm{PGE}_{\mathbf{2}}$ with enalaprilat on the decidual cell reaction}

Angiotensin II infusion at $2 \mu \mathrm{g} \mathrm{h}^{-1}$ (Table 1) or at $0 \cdot 2 \mu \mathrm{g} \mathrm{h}^{-1}$ (Table 2) failed to reverse the effect of enalaprilat on the weights of infused uterine horns; angiotensin III infusion at a rate of $2 \mu \mathrm{g}$ $\mathrm{h}^{-1}$ was also ineffective (Table 2). However, infusion of $\mathrm{PGE}_{2}$ caused a significant reversal $(P<0.01)$ of the inhibitory response to enalaprilat (Table 1), although it did not fully restore uterine weights to those of uteri infused with vehicle. The dose of $\mathrm{PGE}_{2}$ used was that shown to override fully the inhibition of the decidual cell reaction produced by indomethacin (Kennedy \& Lukash, 1982). $\mathrm{PGF}_{2 a}\left(1 \mu \mathrm{g}\right.$ acid equivalents $\left.\mathrm{h}^{-1}\right)$ did not reverse the effect of enalaprilat, nor did addition of $\mathrm{PGF}_{2 \alpha}$ to the infusion of enalaprilat plus $\mathrm{PGE}_{2}$ produce uterine weights that were statistically different from those produced by enalaprilat plus $\mathrm{PGE}_{2}$ only (Table 2).

\section{Effects of enalaprilat and angiotensin II on endometrial alkaline phosphatase activity}

Animals receiving intrauterine infusion of vehicle showed a seven fold increase in endometrial alkaline phosphatase activity in infused uterine horns compared with noninfused uterine horns 


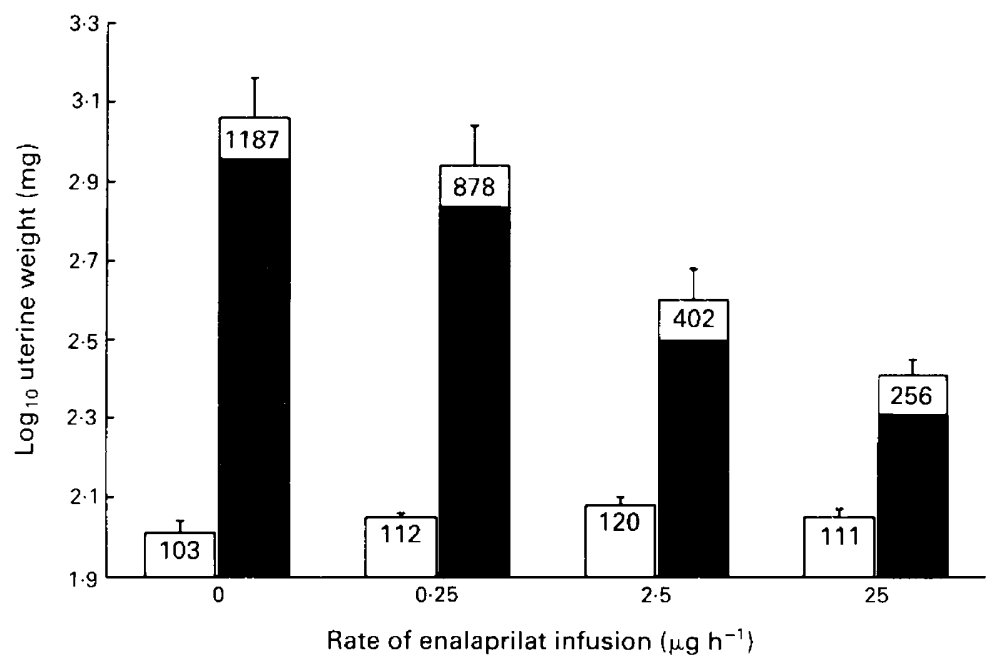

Fig. 1. Effects of unilateral intrauterine infusion of the control solution $\left(25.1 \mathrm{mg}\right.$ mannitol $\mathrm{ml}^{-1}$ in $20 \%$ dimethyl sulfoxide in $0.05 \mathrm{~mol}$ sodium phosphate buffer $\mathrm{l}^{-1}, \mathrm{pH} 7 \cdot 4,1 \mu \mathrm{h} \mathrm{h}^{-1}$ ) or enalaprilat $\left(0 \cdot 25-25 \mu \mathrm{g} \mathrm{h}^{-1}\right)$ for 5 days on wet weights of infused (solid bars) and noninfused (open bars) uterine horns of rats. Each bar represents the mean \pm SEM of the logarithmically transformed data from seven rats. Geometric mean of uterine weight is given at the top of each bar.

$(P<0.01)$; this response was significantly reduced by infusion of enalaprilat $(P<0.01)$, an effect that was not reversed by concurrent infusion of angiotensin II $\left(2 \mu \mathrm{g} \mathrm{h}^{-1}\right)$ (Table 1).

\section{Effects of enalaprilat, angiotensin II and $\mathrm{PGE}_{2}$ on endometrial vascular permeability}

Changes in endometrial vascular permeability were assessed, using ${ }^{125}$ I-labelled-BSA, $10 \mathrm{~h}$ after the implantation of the pumps. Animals receiving vehicle infusions showed significantly greater $(P<0.01)$ retention of radioactivity in infused horns than in noninfused horns, and this response was reduced approximately $70 \%$ by infusion of enalaprilat $(P<0.01$; Table 1). Again, concurrent infusion of angiotensin II $\left(2 \mu \mathrm{g} \mathrm{h}^{-1}\right)$ did not reverse the inhibition by enalaprilat; concentrations of radioactivity in the group treated with $\mathrm{PGE}_{2}$ were also not statistically different from those in the group treated only with enalaprilat.

\section{Effect of enalaprilat infusion on uterine PG levels}

There were no significant differences between treatment groups in the concentrations of either $P G$ in noninfused horns, but infusion of the vehicle induced large increases in the concentrations of both $\mathrm{PGE}$ and $\mathrm{PGF}_{2 \alpha}$ in infused uterine horns $(P<0.001)$, and this response was reduced by approximately $80 \%(P<0.01)$ by infusion of enalaprilat.

\section{Effect of enalaprilat and angiotensin II on stromal cell alkaline phosphatase activity}

There was no significant effect of enalaprilat on alkaline phosphatase activity of the stromal cells after $24 \mathrm{~h}$ in culture, but analysis of variance revealed a significant $(P<0.001)$ dosedependent inhibitory effect of enalaprilat, in doses ranging from $10^{-7}$ to $10^{-5} \mathrm{~mol} \mathrm{l}^{-1}$, on alkaline phosphatase activity after $72 \mathrm{~h}$ of culture. Analysis of variance also indicated that this effect was significantly reversed by angiotensin II $(P<0.001)$ at doses ranging from 0.1 to $10 \mu \mathrm{g} \mathrm{ml}^{-1}$ and revealed a significant $(P<0.01)$ interaction between enalaprilat treatment and angiotensin II 


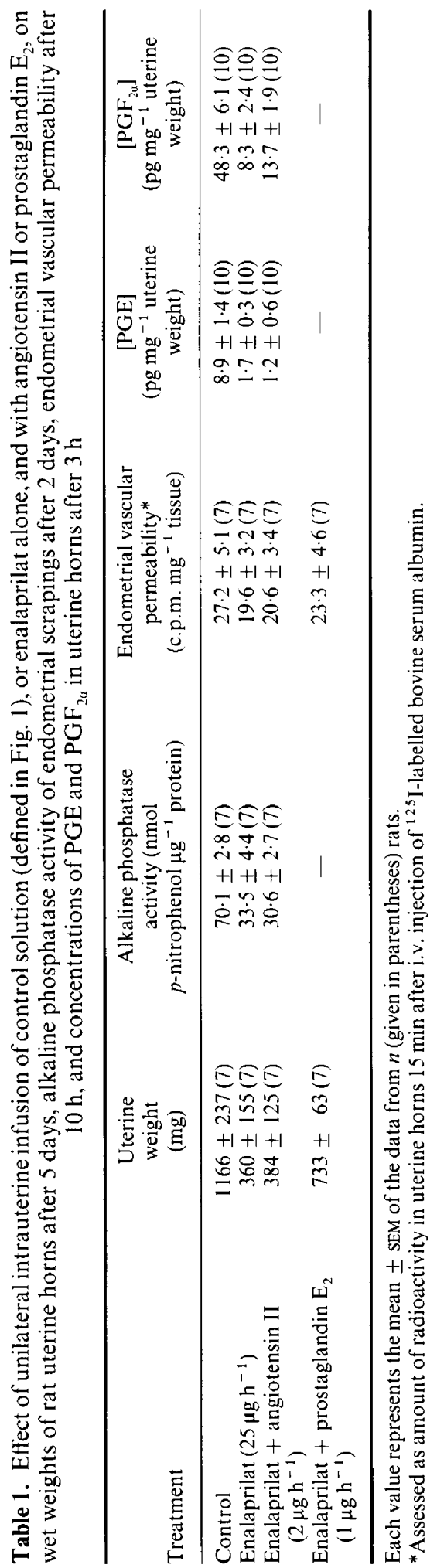


Table 2. The effects of unilateral intrauterine infusion of control solution (defined in Fig. 1), or enalaprilat alone, and with angiotensin II, angiotensin III, prostaglandin $\mathrm{E}_{2}$, prostaglandin $\mathrm{F}_{2 \alpha}$ and $\mathrm{PGE}_{2}$ plus $\mathrm{PGF}_{2 \alpha}$ on wet weights of uterine horns 5 days after the initiation of the infusions

\begin{tabular}{llr}
\hline \multirow{2}{*}{ Experiment } & \multicolumn{1}{c}{ Treatment } & $\begin{array}{c}\text { Uterine weight } \\
\text { (mg) }\end{array}$ \\
\hline 1 & & $1226 \pm 108$ \\
& Control & $400 \pm 46$ \\
& Enalaprilat $\left(25 \mu \mathrm{g} \mathrm{h}^{-1}\right)$ & $452 \pm 77$ \\
& Enalaprilat + angiotensin II $\left(0 \cdot 2 \mu \mathrm{g} \mathrm{h}^{-1}\right)$ & $467 \pm 102$ \\
2 & Enalaprilat + angiotensin III $\left(2 \mu \mathrm{g} \mathrm{h}^{-1}\right)$ & $1174 \pm 148$ \\
& Control & $332 \pm 50$ \\
& Enalaprilat $\left(25 \mu \mathrm{g} \mathrm{h}^{-1}\right)$ & $579 \pm 77$ \\
& Enalaprilat + prostaglandin $\mathrm{E}_{2}\left(1 \mu \mathrm{g} \mathrm{h}^{-1}\right)$ & $344 \pm 27$ \\
& Enalaprilat + prostaglandin $\mathrm{F}_{22}\left(1 \mu \mathrm{g} \mathrm{h}^{-1}\right)$ & $577 \pm 66$ \\
\hline
\end{tabular}

Each value represents the mean \pm SEM of the data from seven rats.

treatment, signifying that the effects of enalaprilat and angiotensin II were not additive; angiotensin II did not significantly increase alkaline phosphatase activity of cells not treated with enalaprilat, whereas it stimulated alkaline phosphatase in enalaprilat-treated cells (Fig. 2a).

\section{Effects of enalaprilat and angiotensin II on PGE concentrations of stromal-cell-conditioned media}

Radioimmunoassay of extracted conditioned media showed a significant inhibitory effect of enalaprilat $\left(10^{-7}\right.$ to $\left.10^{-5} \mathrm{~mol} \mathrm{l}^{-1}\right)$ on concentrations of PGE $(P<0 \cdot 01$; Fig. $2 \mathrm{~b})$ in media exposed to stromal cells on the third day of culture. Angiotensin II reversed this effect, as well as increasing PGE concentrations in media from control cultures $(P<0.01)$, but ANOVA did not indicate an interaction between the two treatments.

\section{Reversal of enalaprilat-induced inhibition of alkaline phosphatase activity by PGE $_{2}$}

The inhibitory effect of enalaprilat on alkaline phosphatase activity was fully reversed by PGE $_{2} \quad(P<0.001)$, suggesting that the mechanism of enalaprilat-induced inhibition of alkaline phosphatase activity involves the inhibition of PGE synthesis by the cultured stromal cells (Fig. 3a).

\section{Effect of angiotensin II on alkaline phosphatase activity in the presence of indomethacin}

Cells were cultured in the presence of enalaprilat $\left(10^{-5} \mathrm{~mol}^{-1}\right)$, with or without indomethacin $\left(10^{-5} \mathrm{~mol}^{-1}\right)$, an inhibitor of prostaglandin synthetase (Fig. 3b) to test whether the ability of angiotensin II to reverse the inhibition of stromal cell alkaline phosphatase by enalaprilat depends on PG synthesis. The significant $(P<0.001)$ inhibitory effect of enalaprilat on stromal alkaline phosphatase activity was not altered by the presence of indomethacin in the cultures; angiotensin II $\left(10 \mu \mathrm{g} \mathrm{ml}^{-1}\right)$ failed to reverse this inhibition in cells treated with enalaprilat plus indomethacin, suggesting that the ability of angiotensin II to override the inhibition in cultures treated with enalaprilat only depends on stimulation of stromal PG synthesis.

\section{Discussion}

Substantial evidence exists for the presence of a local renin-angiotensin system in the uterus of rats (Lin \& Goodfriend, 1970; Cushman \& Cheung, 1971; Gutman \& Mazur-Ruder, 1976), but a 

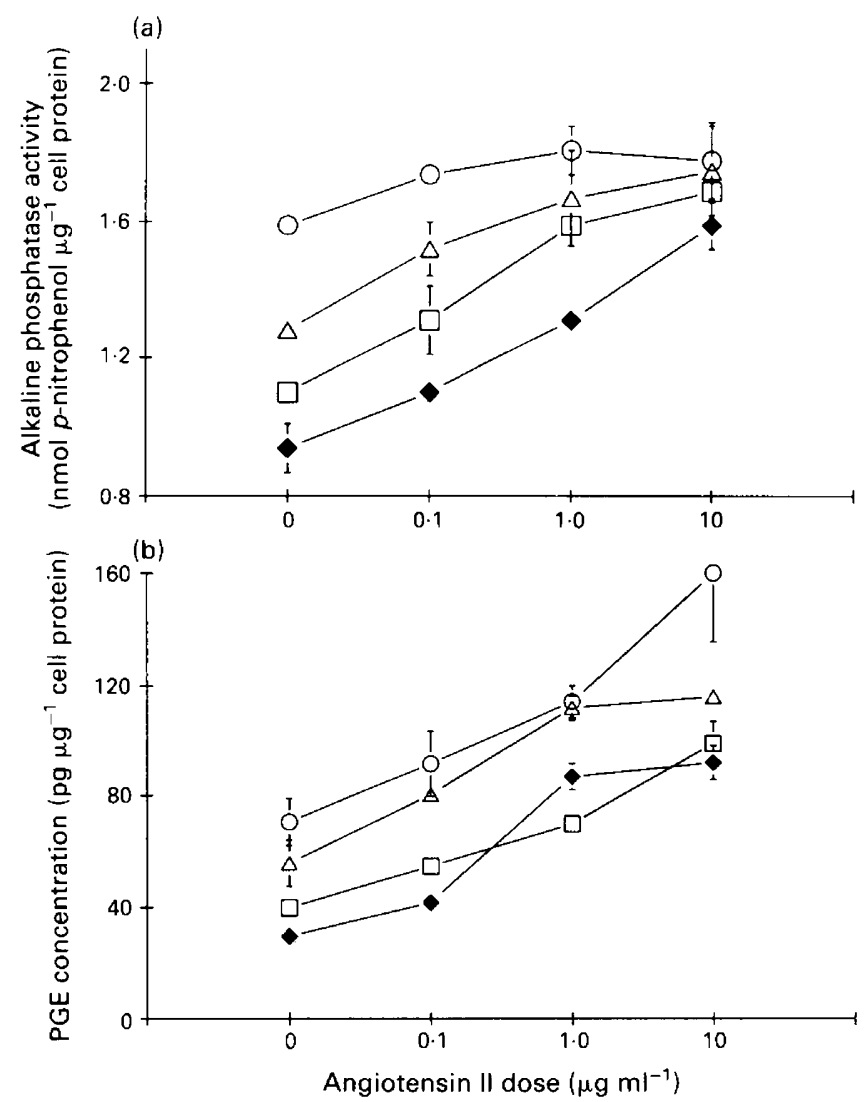

Fig. 2. Effects of combined treatment of endometrial stromal cells with 0 (open circles), $10^{-7}$ (open triangles), $10^{-6}$ (open squares) and $10^{-5}$ (filled diamonds) mol enalaprilat $1^{-1}$ and angiotensin II on (a) stromal alkaline phosphatase activity measured after $72 \mathrm{~h}$ of culture and (b) concentrations of prostaglandin $\mathrm{E}$ in media exposed to stromal cells on the third day of culture. Each point represents the mean \pm SEM of the data from four culture wells.

functional role for this system in the endometrium has not been elucidated. Our results demonstrate that a specific inhibitor of angiotensin-converting enzyme inhibits the increases in uterine PG concentration, endometrial vascular permeability, endometrial alkaline phosphatase activity and uterine weight that occur sequentially after the application of an intrauterine stimulus for decidualization. The inability of enalapril, administered intraluminally, to produce this effect is consistent with the fact that this product must be metabolized by the liver to enalaprilat (Oparil, 1983) to inhibit angiotensin-converting enzyme; its lack of effect provides evidence that enalaprilat acts specifically on this enzyme. These data suggest that production of angiotensin by the endometrium is necessary for maximal decidualization in rats.

There are several possible explanations for the failure of angiotensin II (and angiotensin III) to override the effects of intraluminally administered converting enzyme inhibitor. Gutman \& MazurRuder (1976) have demonstrated a maximum rate of production of angiotensin by rat uterus in vitro of approximately $0.7 \mu \mathrm{g} \mathrm{h}^{-1}$ per uterus, suggesting that the doses of angiotensin peptides used in our experiments were not too small to be effective. The partial reversal of this inhibition by $\mathrm{PGE}_{2}$ suggests that the effect is not due to a nonspecific toxic action of enalaprilat. It is possible that the effect of enalaprilat is not due to blockade of angiotensin II synthesis but to the accumulation of other angiotensin-converting enzyme substrates. This enzyme is responsible for, in addition to angiotensin II formation, the hydrolysis of both bradykinin (Dorer et al., 1974) and substance P 


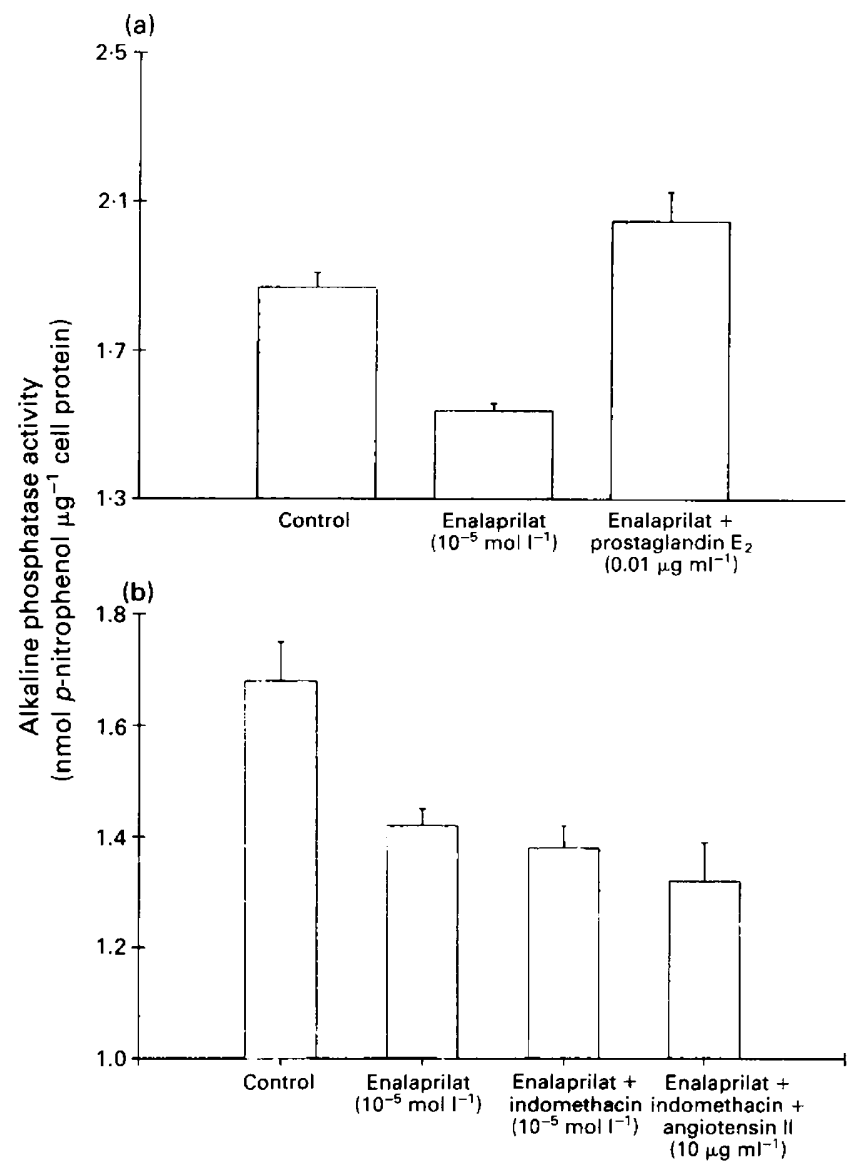

Fig. 3. Effects of treatment of rat endometrial stromal cells with vehicle (control) or enalaprilat, and of combined treatment with (a) enalaprilat and $\mathrm{PGE}_{2}$ and (b) enalaprilat plus indomethacin with and without angiotensin II on activity of stromal cell alkaline phosphatase after $72 \mathrm{~h}$ of culture. Each bar represents the mean \pm SEM of the data from four culture wells.

(Cascieri et al., 1974). However, no data are available for a role for substance $P$ in the decidual cell reaction, and DeFeo (1963) has shown that intraluminal injection of bradykinin stimulates deciduoma formation, so it is unlikely that the accumulation of bradykinin resulting from inhibition of angiotensin-converting enzyme would block decidualization.

The most likely explanation is that the intraluminally infused angiotensin II is restricted to the lumen by the endometrial epithelial cells. These cells have been shown to form a permeability barrier between the lumen and the stroma, and significantly to restrict polar non-electrolytes as small as sucrose on the basis of molecular size (McRae \& Kennedy, 1983). Angiotensin II $\left(M_{\mathrm{r}}=1046\right)$, a peptide, would be retained in the lumen whereas enalaprilat and $\mathrm{PGE}_{2}$, which are smaller, more lipophilic compounds, could more easily diffuse into the uterine tissue. This rationale is supported by our observation that the inhibitory effect of enalaprilat on the increase in alkaline phosphatase activity of cultured endometrial stromal cells, an indicator of the decidual cell reaction in vitro (Daniel \& Kennedy, 1987), can be reversed by angiotensin II.

Isolation and culture of individual types of uterine cell have demonstrated that stromal cells from appropriately sensitized animals undergo spontaneous decidualization in vitro as assessed by development of binucleation and other morphological changes (Vladimirsky et al., 1977; Sananes 
et al., 1978), and by accumulation of decidual-cell-specific intermediate filaments (Glasser \& Julian, 1986; Glasser et al., 1987). This process is specific for stromal cells from animals exposed to progesterone, since cells from untreated ovariectomized animals did not exhibit this transformation (Sananes et al., 1978). This model permits the investigation of factors involved in the regulation of stromal cell differentiation in culture. The increase in endometrial stromal alkaline phosphatase activity that accompanies decidualization in vivo can also be observed in cultured endometrial stromal cells undergoing decidualization in vitro (Daniel \& Kennedy, 1987). This increase in alkaline phosphatase is maximal $24.72 \mathrm{~h}$ after the induction of decidualization both in vivo and in culture (Yee \& Kennedy, 1991), and is stimulated by $\mathrm{PGE}_{2}$ and inhibited by indomethacin both in vivo (Yee \& Kennedy, 1988), as assessed histochemically and biochemically, and in vitro (Daniel \& Kennedy, 1987) as measured by enzyme activity.

This study demonstrates that treatment of cultured endometrial decidual cells with enalaprilat inhibits the increase in alkaline phosphatase activity associated with decidualization in culture, in agreement with the inhibition of endometrial alkaline phosphatase activity by enalaprilat in vivo. Furthermore, we have shown that this inhibition can be fully reversed by angiotensin II in cultured cells, suggesting that the failure of angiotensin II to reverse the inhibition of decidualization by enalaprilat in vivo is due to the restriction of infused angiotensin II to the uterine lumen by the endometrial epithelial cells. These experiments indicate a requirement for local production of angiotensin II in the uterus during decidualization in rats.

Since enalaprilat reduces and angiotensin II restores PGE concentrations in stromal-cellconditioned medium, it appears that the action of angiotensin II on these cells involves stimulation of stromal prostaglandin synthesis. This observation is supported by the ability of $\mathrm{PGE}_{2}$ to reverse fully the inhibitory effect of enalaprilat on stromal alkaline phosphatase activity in the absence of angiotensin $\mathrm{II}$, in contrast with its ability to reverse only partially the inhibitory effect of enalaprilat on decidualization in vivo. The fact that there was an interaction between enalaprilat and angiotensin II for stimulation of alkaline phosphatase activity (i.e. angiotensin II stimulated alkaline phosphatase activity in the presence of enalaprilat but not in its absence) but no interaction between these two treatments for PGE concentrations in media (i.e. angiotensin II increased PGE concentrations even in the absence of enalaprilat) suggests that alkaline phosphatase activity in cultures not treated with enalaprilat was maximally stimulated, such that further increases in media PGE concentration induced by angiotensin II would have no effect on alkaline phosphatase. The failure of angiotensin II to reverse the inhibition of stromal alkaline phosphatase by enalaprilat in the presence of indomethacin indicates that the effect of angiotensin II on cultured stromal cell alkaline phosphatase activity is wholly prostaglandin-dependent; the effect of $\mathrm{PGE}_{2}$ on enalaprilatinduced inhibition of decidualization in vivo suggests that a PG-independent mechanism is also involved. Since the dose and method of administration of $\mathrm{PGE}_{2}$ used was sufficient to reverse fully the inhibition of decidualization resulting from intrauterine infusion of indomethacin (Kennedy \& Lukash, 1982), it is unlikely that limited access of $P G E_{2}$ to the site of action or rapid breakdown of $\mathrm{PGE}_{2}$ in vivo are responsible for the lack of full effectiveness of this substance in vivo. As $\mathrm{PGE}_{2}$ did not reverse the inhibitory effect of enalaprilat on endometrial vascular permeability, it can be postulated that the suggested PG-independent mechanism may operate at an earlier stage of decidualization than the PG-dependent mechanism.

The stimulation of PG production by angiotensin in cultured endometrial stromal cells is consistent with the effects of angiotensin II in vascular tissue (Robertson \& Khairallah, 1972; Gimbrone \& Alexander, 1975) and adrenal glomerulosa (Campbell et al., 1979). The effects of angiotensin on permeability in various vascular beds appear to involve the local production of prostaglandins such as PGE (Robertson \& Khairallah, 1972; Gimbrone \& Alexander, 1975). In addition, the mediation of angiotensin-II-induced increases in uterine blood flow by PGE $_{2}$ in monkeys supports the hypothesis that a proposed role for angiotensin II in the decidual cell reaction may involve $P G$ synthesis, as suggested by the partial reversal of the inhibitory effect of enalaprilat on uterine weight by co-infusion of $\mathrm{PGE}_{2}$, and by enalaprilat-induced reduction of 
uterine PG concentrations. The present experiments, however, do not distinguish between angiotensin II and III, the latter being a more potent stimulator of PG release in other tissues (Blumberg et al., 1976).

In summary, these experiments suggest a requirement for angiotensin-converting enzyme activity and angiotensin II production for maximal expression of the decidual cell reaction in rats. The proposed role of angiotensin II in decidualization appears to involve endometrial synthesis of PGs, as well as a mechanism of action that may be independent of PGs. In identified angiotensin target tissues, the interaction of angiotensin II with its receptor is thought to involve increases in intracellular calcium concentration, phosphoinositide turnover and diacylglycerol production with accompanying activation of protein kinase C (Goodfriend, 1983; Griendling et al., 1988). Studies are currently under way to determine whether a calcium-dependent mechanism accounts for the discrepancy between the ability of $\mathrm{PGE}_{2}$ to reverse inhibition by angiotensin-converting enzyme of decidualization in vivo and in vitro.

We acknowledge the excellent technical assistance of P. E. Doktorcik and H. E. Ross. This work was supported by grant number MA-10414 from the Medical Research Council of Canada. P. Squires is the recipient of an MRC Studentship.

\section{References}

Blumberg, A., Denny, S., Nishikawa, K., Pure, E. Marshall, G.R. \& Needleman, P. (1976) Angiotensin III-induced prostaglandin (PG) release. Prostaglandins 11, 195-197.

Bruce, S.L., Morishima, H.O., Petrie, R.H., Sukuma, K., Daniel, S.S. \& Yeh, S.-Y. (1981) Response of ovine uterine blood flow to angiotensin II: Effect on the fetus. American Journal of Obstetrics and Gynecology 141, 495-498.

Campbell, W.B., Gomez-Sanchez, C.E., Adams, B.V., Schmitz, J.M. \& Itskovitz, H.D. (1979) Attenuation of angiotensin II- and III-induced aldosterone release by prostaglandin synthesis inhibitors. Journal of Clinical Investigation 64, 1552-1557.

Cascieri, M.A., Bull, H.G., Mumford, R.A., Patchett, A.A., Thornberry, N.A. \& Liang, T. (1974) Carboxyterminal tripeptidyl hydrolysis of substance $P$ by purified rabbit lung angiotensin-converting enzyme and the potentiation of substance $P$ activity by captopril and MK-422. Molecular Pharmacology 25, 287-293.

Christie, G.A. (1966) Implantation of the rat embryo: glycogen and alkaline phosphatases. Journal of Reproduction and Fertility 12, 279-294.

Cushman, D.W. \& Cheung, H.S. (1971) Concentrations of angiotensin-converting enzyme in tissues of the rat. Biochimica et Biophysica Acta 250, 261-265.

Daniel, S.A.J. \& Kennedy, T.G. (1987) Prostaglandin $\mathrm{E}_{2}$ enhances uterine stromal cell alkaline phosphatase activity in vitro. Prostaglandins 33, 241-252.

Deboben, A., Inagami, T. \& Ganten, D. (1983) Tissue renin. In Hypertension, Pathophysiology and Treatment, pp. 194-209. Eds J. Genest, O. Kuchel, P. Hamet \& M. Cantin. McGraw Hill, New York.

DeFeo, V.J. (1963) Determination of the sensitive period for the induction of deciduomata in the rat by different inducing procedures. Endocrinology 73, 488-497.

Dorer, F.E., Khan, J.R., Lentz, K.E., Levine, M. \& Skeggs, T. (1974) Hydrolysis of bradykinin by angiotensin-converting enzyme. Circulation Research 34, 824-827.

Edwards, C. \& Milligan, S.R. (1987) Uterine blood flow during the development and regression of the decidual cell reaction in ovariectomized, steroidtreated mice. Journal of Reproduction and Fertility 81, $525-532$.

Fernandez, L.A., Caride, V.J., Twickler, J. \& Galardy, R.E. (1982) Renin-angiotensin and development of collateral circulation after renal ischemia. American Journal of Physiology 243, H869-875.

Fernandez, L.A., Twickler, J. \& Mead, A. (1985) Neovascularization produced by angiotensin II. Journal of Laboratory and Clinical Medicine 105, 141-145.

Ferris, T.F. \& Weir, E.K. (1983) Effect of captopril on uterine blood flow and prostaglandin E synthesis in the pregnant rabbit. Journal of Clinical Investigation $71,809-815$.

Finn, C.A. \& Keen, P.M. (1963) The induction of deciduomata in the rat. Journal of Embryology and Experimental Morphology 11, 673-682.

Gimbrone, M.A. \& Alexander, R.W. (1975) Angiotensin II stimulation of prostaglandin production in cultured human vascular endothelium. Science 189, 219-220.

Glasser, S.R. \& Julian, J. (1986) Intermediate filament protein as a marker of uterine stromal cell decidualization. Biology of Reproduction 35, 463-474.

Glasser, S.R. \& Lampelo, S., Munir, M.I. \& Julian, J. (1987) Expression of desmin, laminin and fibronectin during in situ differentiation (decidualization) of rat uterine stromal cells. Differentiation 35, 132-142.

Goodfriend, T.L. (1983) Angiotensin receptors and specific functions of angiotensins I, II and III. In: Hypertension, Pathophysiology and Treatment, pp. 271-279. Eds J. Genest, O. Kuchel, P. Hamet \& M. Cantin. McGraw Hill, New York.

Griendling, K.K., Berk, B.C., Socorro, L., Tsuda, T., Delafontaine, P. \& Alexander, R.W. (1988) Secondary 
signalling mechanisms in angiotensin II-stimulated vascular smooth muscle cells. Clinical and Experimental Pharmacology and Physiology 15, 105-112.

Gutman, Y. \& Mazur-Ruder, M. (1976) Rat uterus reninlike activity: effect of stimuli and hormones. British Journal of Pharmacology 56, 285-292.

Kennedy, T.G. (1979) Prostaglandins and increased endometrial vascular permeability resulting from the application of an artificial stimulus to the uterus of the rat sensitized for the decidual cell reaction. Biology of Reproduction 20, 560-566.

Kennedy, T.G. (1980a) Timing of uterine sensitivity for the decidual cell reaction: Role of prostaglandins. Biology of Reproduction 22, 519-525.

Kennedy, T.G. (1980b) Estrogen and uterine sensitivity for the decidual cell reaction: Role of prostaglandins. Biology of Reproduction 23, 955-962.

Kennedy, T.G. (1985) Evidence for the involvement of prostaglandins throughout the decidual cell reaction in the rat. Biology of Reproduction 33, 140-146.

Kennedy, T.G. (1986) Intrauterine infusion of prostaglandins and decidualization in rats with uteri differentially sensitized for the decidual cell reaction. Biology of Reproduction 34, 327-335.

Kennedy, T.G. \& Lukash, L.A. (1982) Induction of decidualization in rats by the intrauterine infusion of prostaglandins. Biology of Reproduction 27, 253-260.

Lin, S.-Y. \& Goodfriend, T.L. (1970) Angiotensin receptors. American Journal of Physiology 218, 1319-1328.

Lobel, B.L., Tic, L. \& Shelesnyak, M.C. (1965) Studies on the mechanism of nidation. XVII. Histochemical analysis of decidualization in the rat. Part 3: Formation of the deciduomata. Acta Endocrinologica 50, $517-536$.

Lowry, O.H. (1957) Micromethods for the assay of enzymes. Methods in Enzymology 4, 371-372.

Lowry, O.H., Rosebrough, N.J., Farr, A.L. \& Randall, R.J. (1951) Protein measurement with the Folin phenol reagent. Journal of Biological Chemistry 193, 265-275.

McCormack, S.A. \& Glasser, S.R. (1980) Differential response of individual uterine cell types from immature rats treated with estradiol. Endocrinology 106, 1634-1649.

McRae, A.C. \& Kennedy, T.G. (1983) Selective permeability of the blood-uterine lumen barrier in rats: importance of molecular size. Biology of Reproduction 29, 879-885.

Manning, J.P., Steinetz, B.G. \& Giannina, T. (1969) Decidual alkaline phosphatase activity in the pregnant and pseudopregnant rat. Annals of the New York Academy of Sciences 166, 482-509.
Naruse, M., Naruse, K., Kurimoto, F., Sakurai, H., Yoshida, S., Toma, H., Ishii, T., Obana, K., Demura, H., Inagami, T. \& Shizume, K. (1985) Evidence for the existence of des-asp ${ }^{1}$-angiotensin II in human uterine and adrenal tissues. Journal of Clinical Endocrinology and Metabolism 61, 480-483.

Oparil, S. (1983) Angiotensin I converting enzyme inhibitors and analogues of angiotensin II. In Hypertension, Pathophysiology and Treatment, pp. $250-270$. Eds J. Genest, O. Kuchel, P. Hamet \& M. Cantin. McGraw Hill, New York.

Psychoyos, A. (1973) Endocrine control of egg implantation. In Handbook of Physiology, Section 7, Vol. II, Part 2, pp. 187-215. Eds R. O. Greep, E. B. Astwood \& S. R. Geiger. Bethesda American Physiological Society, Bethesda.

Robertson, A.L. \& Khairallah, P.A. (1972) Effects of angiotensin II and some analogues on vascular permeability in the rabbit. Circulation Research 31, 923-931.

Sananes, N., Weiller, S., Baulieu, E.E. \& LeGoascogne, C. (1978) In vitro decidualization of rat endometrial cells. Endocrinology 103, 86-95.

Snedecor, G.W. \& Cochrane, W.G. (1967) Statistical Methods, pp. 296-298. The Iowa State University Press, Ames.

Speroff, L., Haning, R.V. \& Levin, R.M. (1977) The effect of angiotensin II and indomethacin on uterine artery blood flow in pregnant monkeys. Obstetrics and Gynecology 50, 611-614.

Steele, R.G.D. \& Torrie, J.H. (1960) Principle and Procedures of Statistics, pp. 107-109. McGraw Hill, New York.

Vladimirsky, F., Chen, L., Amsterdam, A., Zor, U. \& Lindner, H.R. (1977) Differentiation of decidual cells in cultures of rat endometrium. Journal of Reproduction and Fertility 49, 61-68.

Yee, G.M. \& Kennedy, T.G. (1988) Stimulatory effects of prostaglandins upon endometrial alkaline phosphatase activity during the decidual cell reaction in the rat. Biology of Reproduction 38, 1129-1136.

Yee, G.M. \& Kennedy, T.G. (1991) Role of cyclic adenosine $3^{\prime}: 5^{\prime}$ monophosphate (cAMP) in mediating the effect of prostaglandin $\mathrm{E}_{2}$ on decidualization in vitro. Biology of Reproduction 45, 163-171.

Yochim, J.M. \& DeFeo, V.J. (1963) Hormonal control of the onset, magnitude and duration of uterine sensitivity in the rat by steroid hormones of the ovary. Endocrinology 72, 317-326.

Received 18 June 1991 